\title{
Relation between recent glacier variations and climate in the Tien Shan mountains, central Asia
}

\author{
LiU ChaOHai and Han Tianding \\ Lanzhou Institute of Glaciology and Geocryology, Academia Sinica, Lanzhou 730000, China
}

\begin{abstract}
Since the Little Ice Age, most glaciers in the Tien Shan mountains have been retreating. Owing to an increase in precipitation in most parts of the mountains during the late 1950s to early 1970 s, the percentage of receding glaciers and the speed of retreat have tended to decrease in the 1970s. However, the general trend of continuous glacier retreat remains unchanged, in part because the summer air temperature shows no tendency to decrease.

In the Tien Shan mountains, as the degree of climatic continentality increases the mass balance becomes more dependent on summer temperature, and accumulation and ablation tend to be lower. Therefore, the responses of glaciers to climatic fluctuations in more continental areas are not synchronous with those in less continental areas, and the amplitude of the glacier variations becomes smaller.
\end{abstract}

\section{INTRODUCTION}

The Tien Shan mountains, between 40 and $50^{\circ} \mathrm{N}$, and 67 and $95^{\circ} \mathrm{E}$, extend $2450 \mathrm{~km}$ from their western section in the Soviet Union to the eastern section in China. All rivers originating from the Tien Shan mountains are part of an inland river system. Apart from several larger rivers, such as the Ili, Syr Dary, and Aksu Rivers, most are isolated piedmont streamlets (Fig. 1). There are 16396 glaciers with a combined area of $16427 \mathrm{~km}^{2}$ and estimated volume of $1369 \mathrm{~km}^{3}$ in the Tien Shan mountains.

Water in this inland arid area comes largely from alpine glaciers. Therefore, glacier variations have an important influence on the water resources. Glacier variations, including their length, area, and volume, are not only the direct result of present climatic change, but

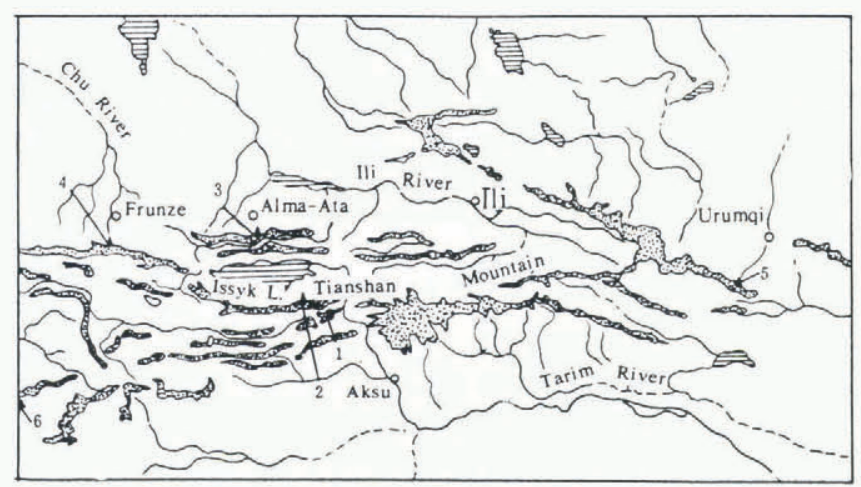

Fig. 1. Location of glacier observation stations in the Tien Shan mountains. 1. Sary-Tor, 2. Karabatkak, 3. Tuyuksu, 4. Golubin, 5. Glacier No. 1, 6. Abramov. also provide an historical record of earlier climatic variations. The climate affects the glaciers through glacier mass gain and loss. This paper tries to elucidate the causes of glacier variations through analysis of Tien Shan glacier changes and the relation between mass balance and climate.

\section{TREND OF GLAGIER VARIATIONS AND REGIONAL CHARACTERISTICS}

In the Tien Shan mountains, statistical data from 74 glaciers indicate that the glaciers have tended to retreat since the Litte Ice Age (Anon, 1988; Zhang and Mi, 1981). However, the retreat can be divided into two stages. From the late 1950 s to the early 1970 s the number of retreating glaciers was large, as was the magnitude of the retreat, while from the early 1970s to the end of the 1980 s fewer glaciers were retreating and the magnitude of the retreats was smaller (Table 1).

In the Akshiyrak Massif, from comparison of aerial photographs taken in 1934 and 1977, it can be seen that 147 glaciers $(83 \%)$ retreated, $24(13 \%)$ were stable, and 7 $(4 \%)$ advanced. In this period of 34 years, the glacier area was reduced by $14 \mathrm{~km}^{2}$, or $4 \%$ of the 1934 glacier area, and glacier volume decreased $3.57 \mathrm{~km}^{3}$, corresponding to a specific net balance of $-256 \mathrm{~mm} \mathrm{a}^{-1}$ (Kuz'michenok, 1989).

The retreat rate of most of the glaciers in the Tien Shan has decreased slightly since the early 1970s. For example, from the late 1950 s to the early 1970s, the annual retreat rate of Tuyuksu Glacier averaged $17.5 \mathrm{~m} \mathrm{a}^{-1}$, whereas, from the early $1970 \mathrm{~s}$ to the mid $1980 \mathrm{~s}$, the retreat rate averaged $14 \mathrm{~m} \mathrm{a}^{-1}$. Glacier No. 1, situated in the eastern Tien Shan, retreated at a mean 
Liu Chaohai and Han Tianding: Glacier-climate relations in Tien Shan

Table 1. Recent changes in glaciers in the Tien Shan mountains

\begin{tabular}{lcccccccc}
\hline Period & \multicolumn{3}{c}{ Retreat } & \multicolumn{3}{c}{ Advance } & \multicolumn{2}{c}{ Stable } \\
& number & $\%$ & $\begin{array}{l}\text { magnitude } \\
\text { of change }\end{array}$ & number & $\%$ & $\begin{array}{l}\text { magnitude } \\
\text { of change }\end{array}$ & number & $\%$ \\
\hline $1960-1970$ & 49 & 66.2 & $1.2-27.3$ & 9 & 12.2 & $3.3-22.4$ & 16 & 21.6 \\
$1971-1985$ & 45 & 60.8 & $0.8-20.8$ & 12 & 16.2 & $1.2-10.5$ & 17 & 23.0 \\
\hline
\end{tabular}

Table 2. Variations of annual precipitation, $P_{\mathrm{a}}$, and mean summer temperature, $T_{\mathrm{s}}$, in the Tien Shan and in the Alps

\begin{tabular}{|c|c|c|c|c|c|c|c|}
\hline \multirow[t]{2}{*}{ Station } & \multirow{2}{*}{$\begin{array}{l}\text { Period } \\
\text { year }\end{array}$} & \multicolumn{3}{|c|}{$T_{s},{ }^{\circ} \mathrm{C}$} & \multicolumn{3}{|c|}{$P_{s}, m m$} \\
\hline & & $T_{\mathrm{s}}$ & $R_{\mathrm{a}}$ & $\sigma$ & $P_{\mathrm{s}}$ & $R_{\mathrm{a}}$ & $\sigma$ \\
\hline \multirow{6}{*}{$\begin{array}{l}\text { Mengyeky } \\
\text { (Tien Shan) }\end{array}$} & 1879-1893 & 3.3 & 3.1 & 0.9 & 1110 & 960 & 240 \\
\hline & $1894-1914$ & 2.6 & 2.9 & 0.7 & 1197 & 1024 & 288 \\
\hline & $1915-1960$ & 3.9 & 3.7 & 0.8 & 1085 & 983 & 224 \\
\hline & $1961-1972$ & 3.8 & 2.7 & 0.8 & 1398 & 810 & 220 \\
\hline & $1973-1987$ & 4.2 & 2.5 & 0.6 & 1113 & 700 & 171 \\
\hline & mean & 3.6 & & & 1148 & & \\
\hline \multirow{4}{*}{$\begin{array}{l}\text { Reckingen } \\
\text { (Alps) }\end{array}$} & $1882-1920$ & 11.6 & 3.2 & 0.8 & 1162 & 903 & 247 \\
\hline & $1921-1960$ & 12.5 & 3.9 & 0.9 & 1211 & 901 & 209 \\
\hline & 1961-1987 & 12.2 & 3.0 & 0.7 & 1278 & 884 & 239 \\
\hline & mean & 12.1 & & & 1210 & & \\
\hline
\end{tabular}

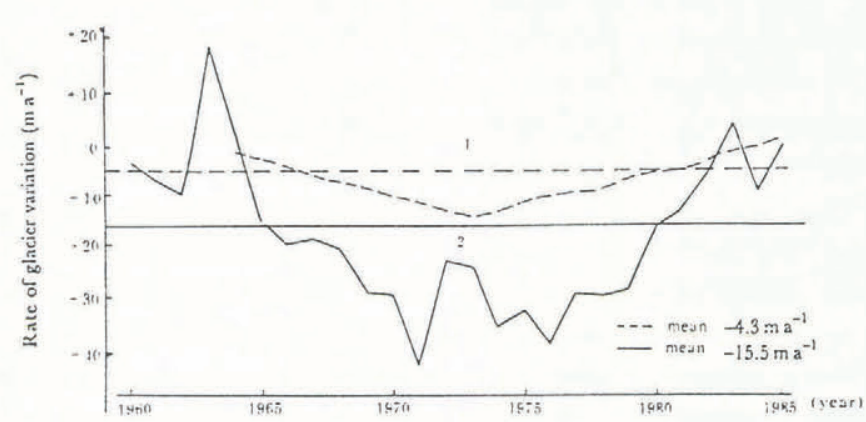

Fig. 2. Cumulative differential curves of the terminus variation of Glacier No. 1 (1) and Tuyuksu Glacier (2). The ordinate is defined by

$$
G=\sum_{i=1}^{n}\left(\dot{R}_{\mathrm{i}}-<\dot{R}>\right)
$$

where $G$ is the cumulative variation in retreat rate, $\dot{R}_{\mathrm{i}}$ is the retreat rate in year $\mathrm{i}$, and $\langle\dot{R}\rangle$ is the mean retreat rate over the period under consideration. rate of $6 \mathrm{ma}^{-1}$ from 1963 to 1973 . Thence to the mid $1980 \mathrm{~s}$, its annual retreat rate averaged $3.3 \mathrm{~m} \mathrm{a}^{-1}$ (Fig. 2). Maritime glaciers that commonly received moisture from the Atlantic, such as those in the Caucasus and Alps, became stable or began to advance in the late 1960s. In contrast, continental glaciers in the Tien Shan mountains continued to retreat, although their retreat rate decreased.

In the Tien Shan mountains, glacier retreat rates decreased with increasing degree of climatic continentality (from western to eastern Tien Shan) and increasing difference in elevation from the highest point on the glacier to the terminus, $\Delta H$. During the last 30 years the annual retreat rate of Tuyuksu Glacier was $-20 \mathrm{~m} \mathrm{a}^{-1}$, while Glacier No. 1 has had an annual retreat of -4 to $-5 \mathrm{~m} \mathrm{a}^{-1}$. There was a similar tendency earlier. Tuyuksu Glacier retreated a total of $740 \mathrm{~m}$ from 1923 to 1984 , exceeding the total retreat of Glacier No. $1,610 \mathrm{~m}$, since the Little Ice Age. 


\section{GLACIER VARIATION AND GLIMATE}

Analysis of records from Mengyeky Meteorological Station ( $3014 \mathrm{~m}$ a.s.l., $43^{\circ} 05^{\prime} \mathrm{N}, 77^{\circ} 04^{\prime} \mathrm{E}$ ) near Tuyuksu Glacier reveals that, since late in the last century, there have been two periods of high precipitation, namely 1894 to 1914 and 1961 to 1972 , when the annual mean precipitation values were respectively 50 and $250 \mathrm{~mm}$ higher than the mean for the period from 1879 to 1985. However, the mean summer temperature has increased since the 1920s (Table 2). Only the high precipitation period from 1894 to 1914 was accompanied by a decrease in temperature; at that time most of the glaciers in the Tien Shan advanced and produced terminal moraine ridges before retreat resumed. In comparison with the Alps that receive moisture from the Atlantic, the annual precipitation and mean summer temperature in the Tien Shan varied nonsynchronously (Fig. 3). Taking Reckingen Station ( $1338 \mathrm{~m}$ a.s.l., $46^{\circ} 28^{\prime} \mathrm{N}, 08^{\circ} 15^{\prime} \mathrm{E}$ ) in the Alps and Mengyeky Meteorological Station in the Tien Shan as examples, since the early 1970s the relatively lower temperatures in the Alps were accompanied by an increase in precipitation, whereas the glaciers in the Tien Shan mountains experienced a period of higher temperatures and less precipitation. Glaciers in the Tien Shan mountains thus retreated.

The synchroneity of annual precipitation and mean summer temperature variations in the Tien Shan becomes weaker with increasing distance between meteorological stations. The correlation coefficients of five-year moving averages in precipitation and mean summer temperature between Mengyeky, Baitik ( $1579 \mathrm{~m}$ a.s.1., $42^{\circ} 19^{\prime} \mathrm{N}$, $\left.74^{\circ} 30^{\prime} \mathrm{E}\right)$, Tien Shan $\left(3614 \mathrm{~m}\right.$ a.s.l., $\left.41^{\circ} 55^{\prime} \mathrm{N}, 78^{\circ} 14^{\prime} \mathrm{E}\right)$, and Daxigou Stations ( $3539 \mathrm{~m}$ a.s.l., $43^{\circ} 06^{\prime} \mathrm{N}, 86^{\circ} 50^{\prime} \mathrm{E}$ ) varied between 0.7 and 0.4. The Mengyeky and Baitik Stations, situated in the moderately humid belt of northern Tien Shan, are closely related with correlation coefficients of 0.7 , but then correlations weaken as distances increase. Tien Shan and Daxigou Stations are closely related again; correlation coefficients are $0.7 \pm 0.02$. Furthermore, the variability, $\sigma$, of annual precipitation and mean summer temperature also decreased with increasing degree of climatic continentality (Table 3). The magnitude of glacier advance or retreat was controlled by the variation in amplitude of the precipitation and mean summer temperature. As the degree of climate continentality increased, retreat rates of glaciers decreased.

\section{GLACIER VARIATON AND MASS BALANCE}

The mass balances of the Golubin, Tuyuksu, and SaryTor Glaciers and of Glacier No. 1 are determined by the west and northwest air currents over the Tien Shan mountains, which determine the formation of precipitation. Differences in precipitation are related to glacier location in the mountains. Both the Tuyuksu and Golubin Glaciers are situated in a moderately humid belt on the western margin of the mountains, and the synchroneity of signs of their mass balances was as high as $85 \%$. The synchroneity of signs decreases with increasing distance from the source of atmospheric precipitation. The synchroneity of Tuyuksu and Golubin Glaciers on

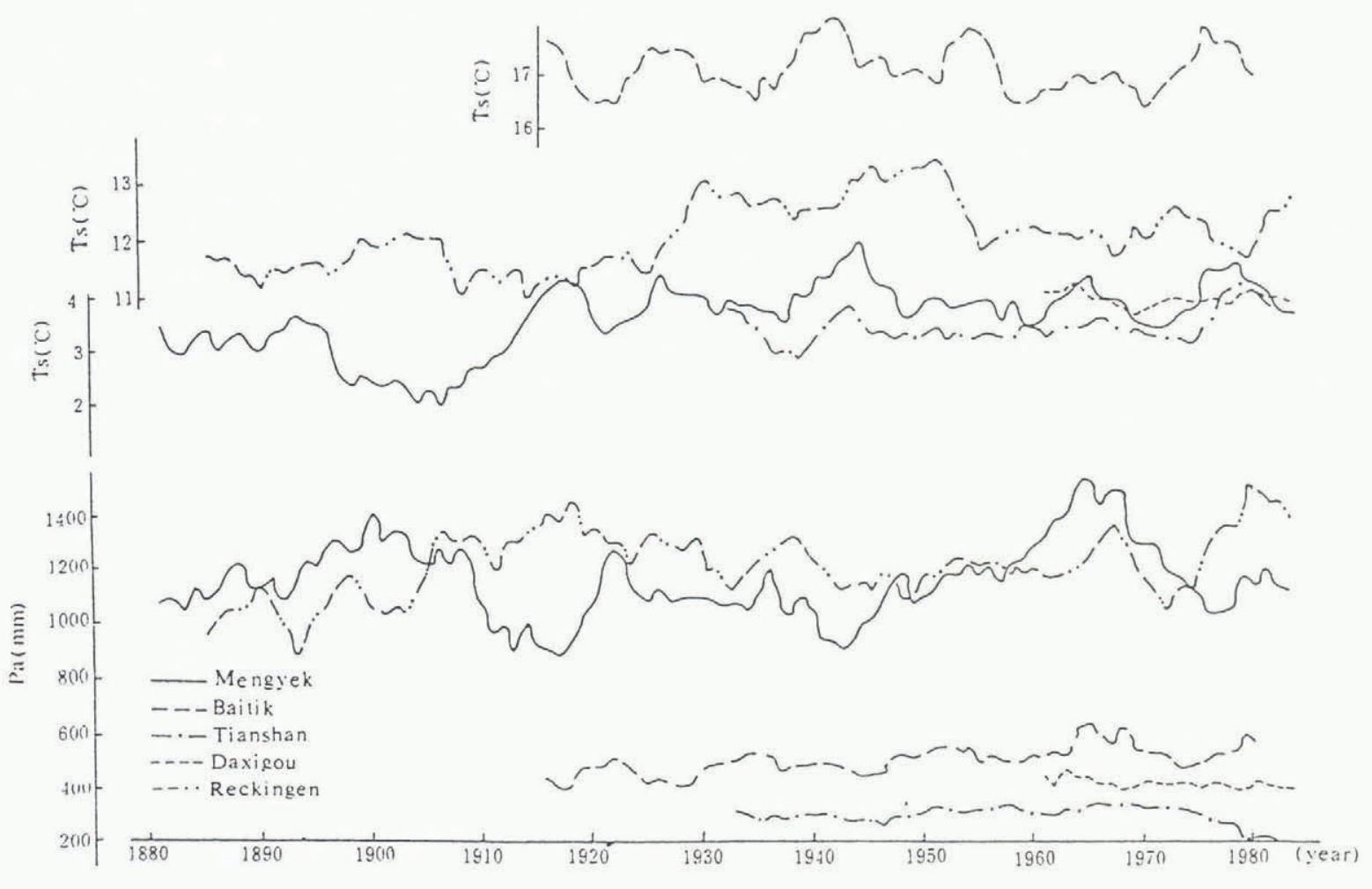

Fig. 3. Five-year moving average curves of annual precipitation $\left(P_{\mathrm{a}}\right)$ and mean summer temperature $\left(T_{\mathrm{s}}\right)$ from several meteorological stations in the Tien Shan. 
Liu Chaohai and Han Tianding: Glacier-climate relations in Tien Shan

Table 3. Variability of mean summer temperature, $T_{\mathrm{s}}$, and annual precipitation, $P_{\mathrm{a}}$, in the Tien Shan mountains

\begin{tabular}{|c|c|c|c|c|c|c|c|}
\hline Station & $\begin{array}{c}\text { Altitude } \\
\text { m }\end{array}$ & $\begin{array}{l}\text { Latitude| } \\
\text { longitude }\end{array}$ & Period & $\begin{array}{l}T_{\mathrm{s}} \\
{ }^{\circ} \mathrm{C}\end{array}$ & $\sigma$ & $\begin{array}{l}P_{\mathrm{a}} \\
\mathrm{mm}\end{array}$ & $\sigma$ \\
\hline Reckingen & 1388 & $\begin{array}{l}46^{\circ} 28^{\prime} \mathrm{N} \\
08^{\circ} 15^{\prime} \mathrm{E}\end{array}$ & $\begin{array}{l}1883-1987 \\
1959-1987\end{array}$ & $\begin{array}{l}12.1 \\
12.2\end{array}$ & $\begin{array}{l}0.91 \\
0.69\end{array}$ & $\begin{array}{l}1210 \\
1271\end{array}$ & $\begin{array}{l}235 \\
237\end{array}$ \\
\hline Mengyeky & 3014 & $\begin{array}{l}43^{\circ} 05^{\prime} \mathrm{N} \\
77^{\circ} 04^{\prime} \mathrm{E}\end{array}$ & $\begin{array}{l}1879-1987 \\
1959-1987\end{array}$ & $\begin{array}{l}3.6 \\
4.0\end{array}$ & $\begin{array}{l}0.98 \\
0.71\end{array}$ & $\begin{array}{l}1149 \\
1239\end{array}$ & $\begin{array}{l}253 \\
235\end{array}$ \\
\hline Baitik & 1579 & $\begin{array}{l}42^{\circ} 19^{\prime} \mathrm{N} \\
74^{\circ} 30^{\prime} \mathrm{E}\end{array}$ & $\begin{array}{l}1914-1982 \\
1959-1982\end{array}$ & $\begin{array}{l}17.2 \\
17.0\end{array}$ & $\begin{array}{l}0.92 \\
0.77\end{array}$ & $\begin{array}{l}515 \\
558\end{array}$ & $\begin{array}{l}105 \\
104\end{array}$ \\
\hline Tien Shan & 3614 & $\begin{array}{l}41^{\circ} 55^{\prime} \mathrm{N} \\
78^{\circ} 14^{\prime} \mathrm{E}\end{array}$ & $\begin{array}{l}1930-1987 \\
1959-1987\end{array}$ & $\begin{array}{l}3.5 \\
3.6\end{array}$ & $\begin{array}{l}0.60 \\
0.57\end{array}$ & $\begin{array}{l}309 \\
315\end{array}$ & $\begin{array}{l}50 \\
53\end{array}$ \\
\hline Daxigou & 3539 & $\begin{array}{l}43^{\circ} 06^{\prime} \mathrm{N} \\
86^{\circ} 50^{\prime} \mathrm{E}\end{array}$ & 1959-1987 & 4.0 & 0.34 & 427 & 47 \\
\hline
\end{tabular}

the one hand, and of Glacier No. 1 on the other, decreased to 50 and $69 \%$, respectively. But synchroneity of mass balance of Sary-Tor Glacier and Glacier No. 1 increased to $85 \%$.

Cumulative differential curves of mass balance can be used to express the directions and trends of mass balance variation. These curves (Fig. 4) are defined by

$$
\gamma=\sum_{i=1}^{n}\left(B_{i}-\bar{B}\right),
$$

where $\gamma$ is the cumulative specific mass balance, $B_{i}$ is the mass balance in year $i$, and $\bar{B}$ is the mean mass balance over the period under consideration. Reconstructed massbalance data for Tuyuksu Glacier and Rhonegletscher Glacier in the Alps, from Vilesov and Guzhavina (1988) and Chen and Funk (1990), respectively, are used as an example. Rhonegletscher and Tuyuksu Glacier have different directions and trends of mass-balance variation (Fig. 4). Since the end of the last century, the mass balance of Tuyuksu Glacier can be divided into three stages: 1879 to 1914 was a period of positive mass balances, with a mean value of $304 \mathrm{~mm} \mathrm{a}^{-1}$ for the period; 1915 to 1973 was a relatively stable period, with small negative mass balances; and from 1973 the mass balance was intensely negative, with a mean value of $-577 \mathrm{~m} \mathrm{a}^{-1}$. The range, and starting and ending times, of the fluctuations of Rhonegletscher are different. The ending of its early period of above-average mass balance was delayed about 13 years. Shortly thereafter, it entered into a period of intensely negative mass balance (1928 to 1955). The mass loss during this period constituted $70 \%$ of the total loss. After the mid-1950s it entered a stable period. Nonsynchroneity of mass-balance variations is the primary cause of these regional differences in glacier variations.

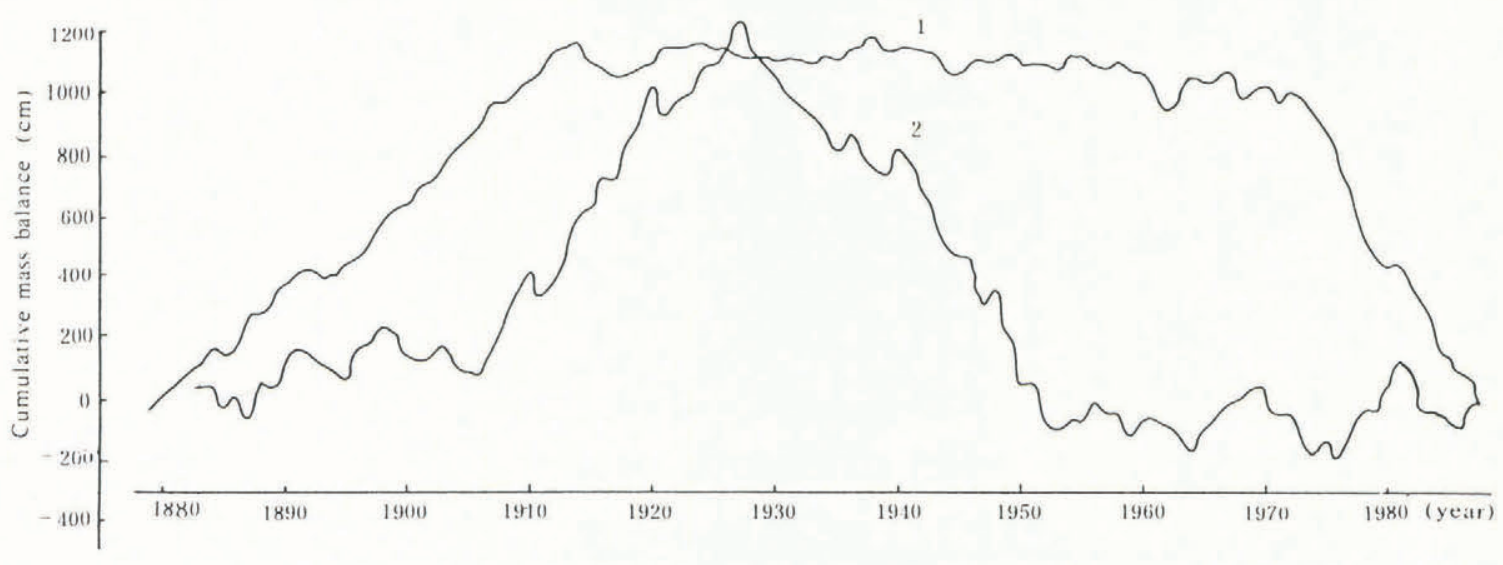

Fig. 4. Cumulative differential curves of mass balance of Tuyuksu Glacier (1) and Rhonegletscher (2). 
Table 4. Mass-balance variability of several glaciers in Tien Shan compared with Rhonegletscher

$\begin{array}{lcccc}\text { Glacier name } & \Delta H^{*} & \text { Period } & \bar{B} & \sigma_{\mathrm{B}} \\ & & \text { year } & \mathrm{cm} & \\ & & & & \\ & & & & \\ \text { Rhonegletscher } & 1930 & 1883-1987 & -24.3 & 66.6 \\ & & 1959-1987 & -22.9 & 59.2 \\ \text { Golubin } & 1100 & 1914-1982 & -12.7 & 30.9 \\ & & 1959-1982 & -5.8 & 26.6 \\ \text { Tuyuksu } & 800 & 1879-1988 & -1.8 & 41.9 \\ & & 1959-1988 & -38.3 & 46.8 \\ \text { Sary-Tor } & 940 & 1930-1988 & -23.6 & 20.2 \\ & & 1959-1988 & -23.7 & 20.6 \\ \text { No. 1 } & 680 & 1959-1988 & -13.5 & 30.3 \\ & & & & \end{array}$

$\Delta H^{*}$ is the difference in elevation between the highest point on the glacier and the terminus.

The sensitivity of glaciers to climatic variations is believed to be related to the variability in mass balance. This is suggested by the fact that the amplitude of annual mass-balance variations decreases with increasing degree of climatic continentality and with $\Delta H$ (Table 4). The variability in mass balance can be expressed by the standard deviation:

$$
\sigma_{\mathrm{B}}=\sqrt{\frac{1}{n} \Sigma(\Delta B)^{2}}
$$

where $\Delta B$ is the difference between the mass balance in a given year and the mean value over the period. The mass balance of Tuyuksu Glacier has large variations in amplitude $\left(\sigma_{\mathrm{B}} \approx 42\right)$. The variability of glacier mass balance decreases with increasing distance from the Tuyuksu Glacier. However, such a relation is affected by geographic location, altitude, and slope-direction. On average, the annual precipitation of Golubin Glacier is $150 \mathrm{~mm}$ less than that of Tuyuksu Glacier, but $\Delta H$ is $300 \mathrm{~m}$ larger on the former. This greatly decreases yearto-year fluctuations in climatic variation and reduces the variability of the mass balance $\left(\sigma_{\mathrm{B}} \approx 31\right)$. The magnitude of advance or retreat of Golubin Glacier is less than that of Tuyuksu Glacier.

Compared with Glacier No. 1, Sary-Tor Glacier has a larger $\Delta H$. In addition, it has lower summer temperatures as a result of the influence of the size of the glacierized region. Therefore, year-to-year fluctuations in its mass balance $\left(\sigma_{\mathrm{B}} \approx 20\right)$ are less than those of Glacier No. 1 .

In summary, in the interior of the Tien Shan, glaciers tend to be retreating at present. The magnitudes of their retreats are correlated with the variability of mass balance.

The heterogeneity of precipitation in space and time has an even greater influence on accumulation, ablation, and mass balance of glaciers. The relative difference of precipitation, $R_{\mathrm{v}}$, can be expressed by:

$$
R_{\mathrm{v}}=\frac{R_{\mathrm{M}}-R_{\mathrm{m}}}{R_{\mathrm{y}}},
$$

where $R_{\mathrm{M}}$ is the monthly maximum precipitation, $R_{\mathrm{m}}$ is the monthly minimum precipitation, and $R_{\mathrm{v}}$ is annual precipitation. From the margin to the interior of the Tien Shan mountains, precipitation can be divided into two types: a transitional type in the western fringe and a continental type in the middle and eastern Tien Shan. The maximum precipitation in these areas occurs in April to May, May to June and June to July, respectively. The period of maximum precipitation thus seems to be delayed with increasing degree of climatic continentality. In other words, the precipitation tends to be concentrated in the summer. The summer precpitation at the western fringe of the Tien Shan is 35\% of the total annual precipitation, while that in the eastern Tien Shan constitutes from 60 to $70 \%$. The regional difference between distribution of annual precipitation and periods of maximum precipitation could affect the glacier accumulation, ablation, and mass balance. As one progresses from the maritime to continental types of precipitation, the winter balance contributes less to the annual mass balance, and accumulation is more concentrated in summer. Therefore, the absolute values of glacier accumulation and ablation are reduced.

The relation between glacier volume, $V$, mass exchange time, $T$, and mass input or output, $A$, can be expressed as follows:

$$
T=\frac{V}{A} .
$$

With the same volume, the lower the mass input, the longer the mass-exchange time. Conversely, with the same mass input, the larger the glacier size, the longer the mass-exchange time. In the Tien Shan mountains the mass input decreases with increasing degree of continentality and the mass-exchange time becomes longer. Therefore, the dynamic response of glaciers to the climatic fluctuation is nonsynchronous and glacier advances or retreats occur at different times in different areas. Generally speaking, glaciers with lower massbalance level and larger size are more stable (Xie, 1980).

\section{CONCLUSIONS}

Since the Little Ice Age, glaciers in the Tien Shan mountains have tended to retreat, except where there were unusually favourable conditions for the glaciers to remain stable or to advance. In the early 1970s, maritime glaciers in the Alps and Caucasus mountains became stable or began to advance, while most glaciers in the Tien Shan mountains only reduced their retreat rate.

The response of glaciers to climatic variations is through mass balance. From the edges of mountains to the interior, glacier winter balance makes a smaller 
contribution to the annual balance, total accumulation and ablation are gradually reduced, and the massexchange time increases. Therefore, the dynamic responses of glaciers to climatic fluctuations are nonsynchronous. Their advances or retreats occur in different periods, and the magnitudes of their retreat or advance are different, too.

\section{REFERENCES}

Anon. 1988. Balans massy i kolebaniya lednikov Sovetskogo Soyuza za 1958-1985 gg. Materialy nablyudeniy [Mass balance and fluctuations of glaciers in the USSR for 1958-1985. Observation data]. Materialy Glyatsiologischeskikh Issledovaniy 62, 224 240.

Chen Jiyang and M. Funk. 1990. Mass balance of Rhonegletscher during 1982/83-1986/87. J. Glaciol., 36(123), 199-209.

Kuz'michenok, V.A. 1989. Teknologiya i vozmozhnosti aerotopograficheskogo kartografirovaniya izmeneniy lednikov (na primere oledeneniya khrebta Akshiyrak) [Technology and possibilities of airborne topographic mapping of glacier fluctuations (with reference to the glaciers of the Akshiyrak Range)]. Materialy Glyatsiologischeskikh Issledovaniy 67, 80-87.

Vilesov, Ye. N. and Ye.A. Guzhavina. 1988. Rekonstruktsiya balansa massy lednika Tuyuksu za posledneye stoletiye [Reconstruction of the mass balance of Tuyuksu Glacier for the last century]. Materialy Glyatsiologischeskikh Issledovaniy 62, 51-58.

Xie Zichu. 1980. Mass balance of glaciers and its relationship with characteristics of glaciers. F. Glaciol. Geopedol., 2(4), 1-10. [In Chinese with English abstract.]

Zhang Xiangsong and Mi Desheng. 1981. Data of recent change of glaciers in China. 7. Glaciol. Geopedol., 3(4), 99-107. [In Chinese.]

The accuracy of references in the test and in this list is the responsibility of the author/s, to whom queries should be addressed. 